\title{
HORMONE LEVELS AND ANTLER DEVELOPMENT IN WHITE-TAILED AND SIKA FAWNS
}

\author{
Robert D. Brown, Chun Chin Chao* and lewis W. Faulkner $\dagger$ \\ Caesar Kleberg Wildlife Research Institute, Texas A\&I University Box 218 , \\ Kingsville, TX 78363 , USA
}

(Received 13 October 1982)

\begin{abstract}
Overall mean values of testosterone (T), androstenedione (A), thyroxine $\left(\mathrm{T}_{4}\right)$, calcium $(\mathrm{Ca})$, phosphorus (P), and alkaline phosphatase (AP) were (T) $2.56 \pm 2.44 \mathrm{ng} / \mathrm{ml}$, (A) $3.16 \pm 2.58 \mathrm{ng} / \mathrm{ml},\left(\mathrm{T}_{4}\right.$ ) $8.22 \pm 4.18 \mu \mathrm{g} / \mathrm{dl},(\mathrm{Ca}), 10.88 \pm 0.65 \mathrm{mg} \%$, (P) $8.03 \perp 0.68 \mathrm{mg}^{\circ}$, and (AP) $81.89 \pm 19.45 \mathrm{IU} / \mathrm{l}$ in whitetailed fawns and (T) $3.69 \pm 2.76 \mathrm{ng} / \mathrm{ml}$, (A) $18.26 \pm 17.58 \mathrm{ng} / \mathrm{ml}, \quad\left(\mathrm{T}_{4}\right) 4.41 \pm 1.59 \mathrm{ug} / \mathrm{dl}$, (Ca) $10.08+0.80 \mathrm{mg} \%$. (P) $9.42 \pm 1.69 \mathrm{mg} \%$ and (AP) $95.35 \pm 22.65 \mathrm{IU} / 1$ in sika fawns.

2. High $T$ titers correlated with antler button growth, and $A$ titers peaked as buttons hardened in both groups.

3. Higher $\mathrm{T}_{4}$ levels in late fall and early winter may have had a synergistic role for button growth in both groups.

4. Generally higher $P$ levels in sika fawns and relatively higher Ca levels in white-tailed fawns might be species dependent.

5. However, relatively constant $\mathrm{Ca}$ and $\mathrm{P}$ in both groups represented mineral homeostasis

6. The mineralization role of AP activity was evident in both groups.
\end{abstract}

\section{INTRODUCTION}

The annual regeneration of antlers by male deer has been found to be a useful model for the study of mineral metabolism and human bone disease (Cowan et al., 1969). Antlerogenesis causes a severe mineral drain on the deer's skeleton which leads to an annual physiological osteoporosis (Meister, 1956; Banks et al., 1968a, b). While the endocrine control of the antler cycle in adult deer has been studied exhaustively, little attention has been given to the initiation of the first antlers in fawns (Sempere \& Boissin, 1982).

White-tailed deer (Odocoileus virginianus) fawns grow small "buttons" rather than antlers their first year, while sika deer (Certus nippon) fawns grow small but complete antlers their first year (Brown, personal observation). Thus these species of young animals offer somewhat different models for the comparative study of the antler growth phenomenon. This project was conducted to examine the hormone titers and other blood parameters of white-tailed and sika fawns in relation to their antler development.

\section{MATERIALS AND METHODS}

Five white-tailed and three sika male fawns were captured in the early summer of 1978 in south Texas. Ages of the fawns at capture were estimated to be between three days and two weeks. While the exact ages of the fawns were not known, they were assumed to be of identical ages for comparative purposes.

* Research Fellow, Rob and Bessie Welder Wildlife Foundation, Sinton, TX 78387, USA.

$\dagger$ Present address: College of Veterinary Medicine, Cornell University, Ithaca, NY 14850, USA.

† Wein Labs Inc., P.O. Box 227, Succasanne, NY 07876 , USA.

$\$$ Hycel Inc., P.O. Box 36329 , Houston, TX 77036, USA.
The fawns were maintained in individual $5 \times 5 \mathrm{~m}$ covered pens, bottle fed on goat's milk, and weaned onto a pelleted ration of $18.0 \%$ protein at approximately four months of age. Beginning in October. blood samples were taken bi-weekly for one year by venepuncture. During the first half of the study, the deer were manually restrained. After 6 months, they were tranquilized with xylazine hydrochloride (Rompun) for handling. Concurrent studies showed that this tranquilizer had no effect on the blood parameters measured (Faulkner et al., 1979). Blood samples were centrifuged, and the serum was stored at $-20^{\circ} \mathrm{C}$ for further analysis.

Testosterone (T). androstenedione (A). and thyroxine $\left(\mathrm{T}_{4}\right)$ titers were measured by radioimmunoassay. All assays utilized rabbit-anti-bovine antibodies which did not cross react with other hormones. The sensitivity of the $T$ and $A$ assays was $10 \mathrm{pg}$. and the $\mathrm{T}_{4}$ assay, $0.1 \mathrm{mg}$. Day to day variation of all assays was $10 \%$ \% Levels of calcium (Ca), inorganic phosphorus (P), and alkaline phosphatase (AP) activity were determined spectrophotometrically:

All data were analyzed using analysis of variance to determine annual changes of each parameter. Pearson's correlation coefficient was calculated with a SPSS program (Gill, 1978) to determine correlations between all bi-weekly data both year-round and in different antler growth stages in both species.

\section{RESULTS}

\section{Antler development}

In the white-tailed fawns, the development of "buttons" (Fig. 1) began in the middle of October. They remained in velvet until the beginning of February when the velvet was rubbed off. The buttons remained hard until the middle of April when they were cast. New antler growth was initiated soon after casting. Rapid growth occurred during the next two months, and the first antlers remained in velvet until the end of the study the following September.

In the sika fawns, antler spikes, rather than buttons appeared the first year. The velvet spikes began grow- 


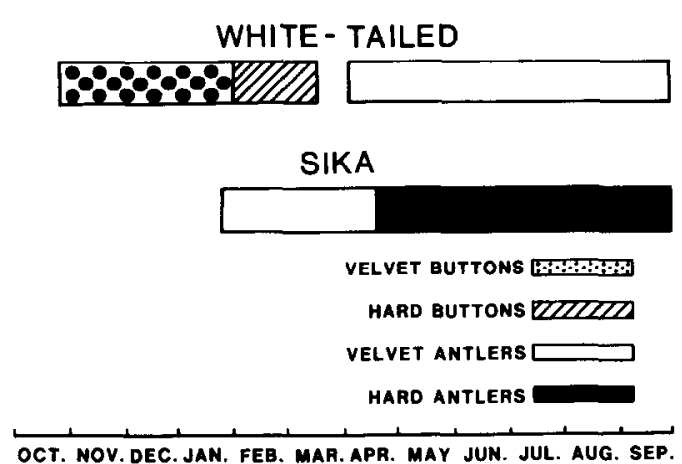

Fig. 1. Comparison of antler development in South Texas white-tailed and sika fawns.

ing at the beginning of January, and the velvet was rubbed off in April. The hardened spikes remained throughout the study period.

\section{Annual cycles of blood parameters}

Elevated $T$ levels (Fig. 2) were found from November to February in the white-tailed fawns. Titers remained low the rest of the year, except for a brief surge in March. In the sika fawns, $T$ levels slowly increased to a peak $(7.57 \mathrm{ng} / \mathrm{ml})$ in January and decreased through the winter. Unlike the white-tails, the sikas' $T$ titers increased again in the spring and peaked $(13.70 \mathrm{ng} / \mathrm{ml})$ in May.

Androstenedione titers (Fig. 3) peaked in both November and March $(9.05$ and $9.60 \mathrm{ng} / \mathrm{ml}$, respectively) in the white-tailed fawns. In the sika fawns, A levels peaked in October, decreased, and then were elevated throughout the summer. The elevated titers were far higher than those of the white-tailed fawns.

White-tailed $\mathrm{T}_{4}$ titers (Fig. 4) peaked in December $(24.85 \mu \mathrm{g} / \mathrm{dl})$, then declined steadily throughout the remainder of the study. In the sika fawns. $T_{1}$ increased and peaked $(10.73 \mu \mathrm{g} / \mathrm{dl})$ in November.
After two months, the titers decreased gradually to the nadir $(2.40 \mu \mathrm{g} / \mathrm{dl})$ in May. A slight increase was seen over the course of the summer. Thyroxine levels in the white-tailed fawns were consistently higher than those in sika fawns.

Serum calcium (Fig. 5) and $P$ levels (Fig. 6) remained relatively constant throughout the year in both groups. However, $\mathrm{Ca}$ levels were slightly higher in the white-tailed fawns, while P levels were higher in sika fawns.

Alkaline phosphatase activity (Fig. 7) in the whitetailed fawns increased gradually throughout the winter and peaked $(110.24 \mathrm{IU} / 1)$ in March. It then dropped sharply to the nadir $(42.5 \mathrm{IU} / \mathrm{l})$ in August. In the sika fawns, AP activity decreased to the nadir (55.5 IU/1) in December, then increased through the winter and peaked $(126.00 \mathrm{IU} / 1)$ in March. Activity remained relatively high in the summer with a drop in late August. Alkaline phosphatase activity was higher in sika fawns in the summer and in the white-tailed fawns in the winter.

\section{Comparison of annual means}

There were no significant differences $(P>0.05)$ between the overall mean values of any of the parameters examined (Table 1). Overall, T titers were fairly close in the two species. Androstenedione was considerably higher in the sika fawns, but the high SE over the year in both species precluded statistical significance. Similarly, $\mathbf{T}_{4}$ titers were higher in whitetails than in sikas, but both species had high SE over the year. Calcium and $P$ levels were very close between the groups. Alkaline phosphatase activity was higher in sika fawns, but again a large SE in both groups prevented a statistical difference.

\section{Correlation coefficients between blood parameters}

In the white-tailed fawns $T$ levels were significantly $(P<0.05)$ correlated with $\mathrm{P}$ and AP $(r=0.44$ and 0.58 , respectively). Androstenedione levels were significantly $(P<0.01)$ correlated with $\mathrm{Ca}, \mathrm{P}$, and AP

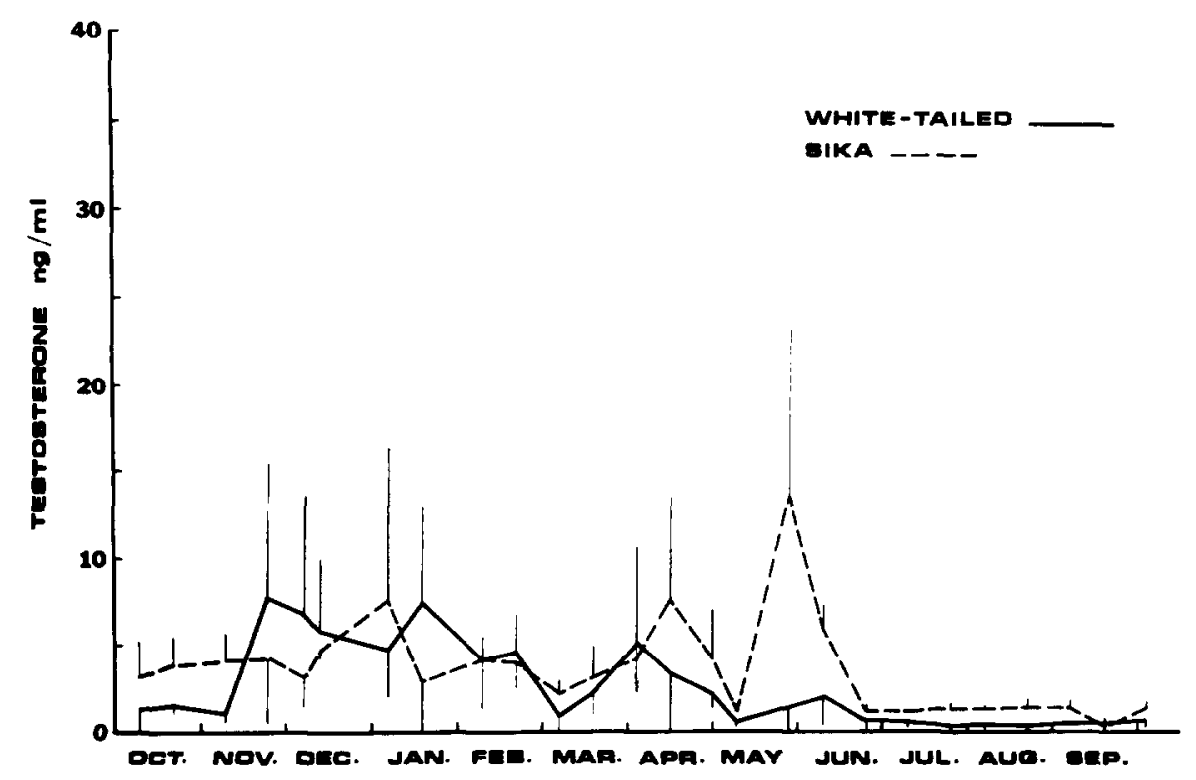

Fig. 2. Annual cycle of testosterone in male white-tailed and sika fawns. 


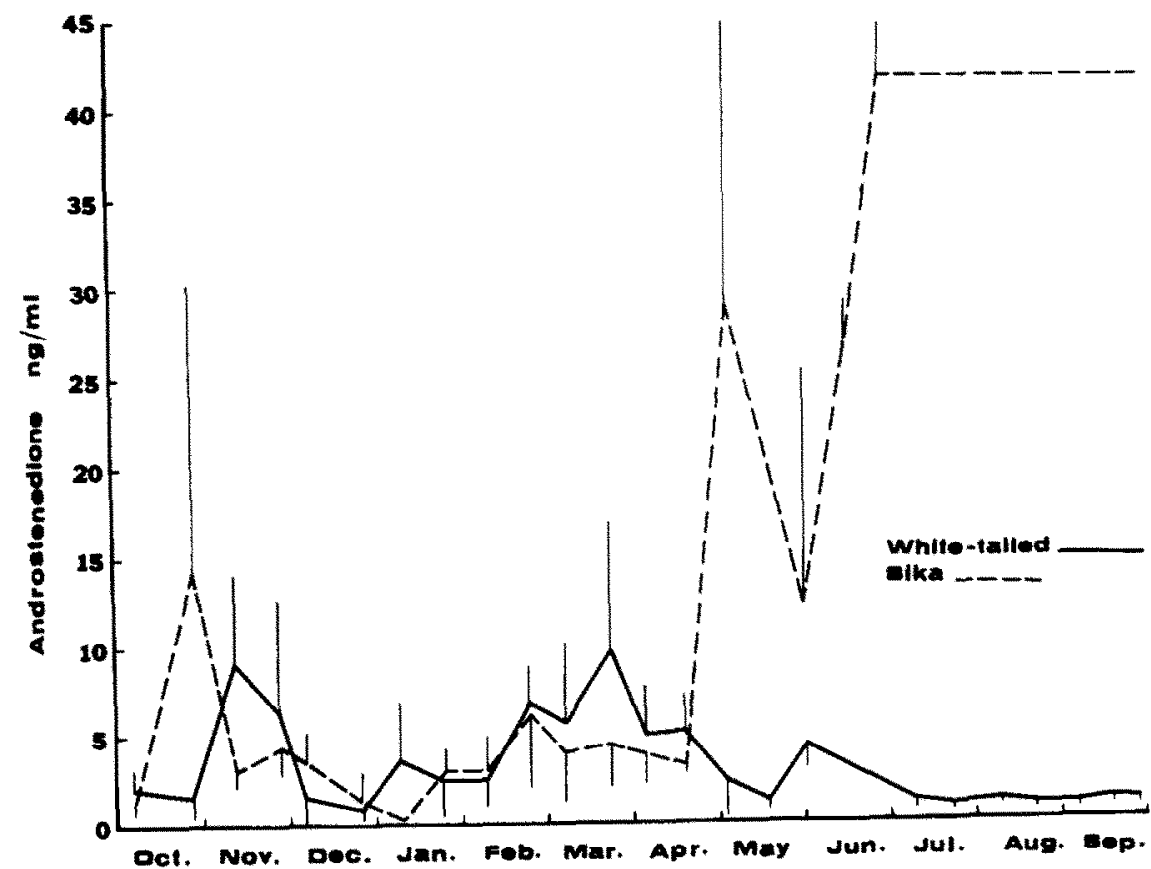

Fig. 3. Annual cycle of androstenedione in male white-tailed and sika fawns.

activity $(r=0.52,0.53$, and 0.64 , respectively). Thyroxine levels were significantly $(P<0.01)$ correlated with $T, C a, P$, and AP activity $(r=0.56,0.52,0.54$. and 0.44 , respectively). Calcium levels were significantly $(P<0.01)$ correlated with $\mathbf{P}$ and AP activity $(r=0.47$ and 0.50 , respectively), while $\mathrm{P}$ levels were correlated $(P<0.001)$ with AP activity $(r=0.73)$.

In the sika fawns, $T$ levels were significantly $(P<0.01)$ correlated with $\mathrm{A}, \mathrm{Ca}$, and $\mathrm{P}$ levels $(r=-0.50,0.60$, and 0.40 , respectively). Androstene-

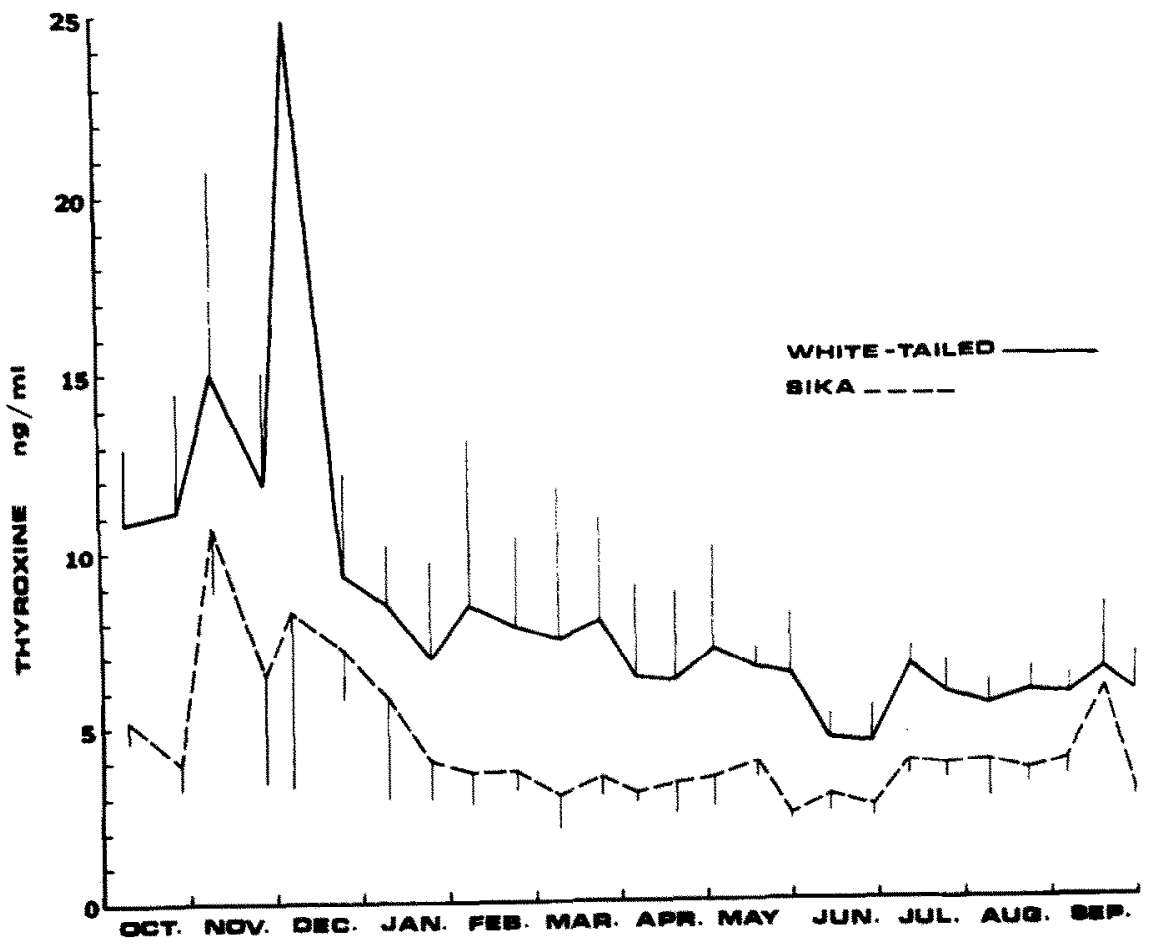

Fig. 4. Annual cycle of thyroxine in male white-tailed and sika fawns. 


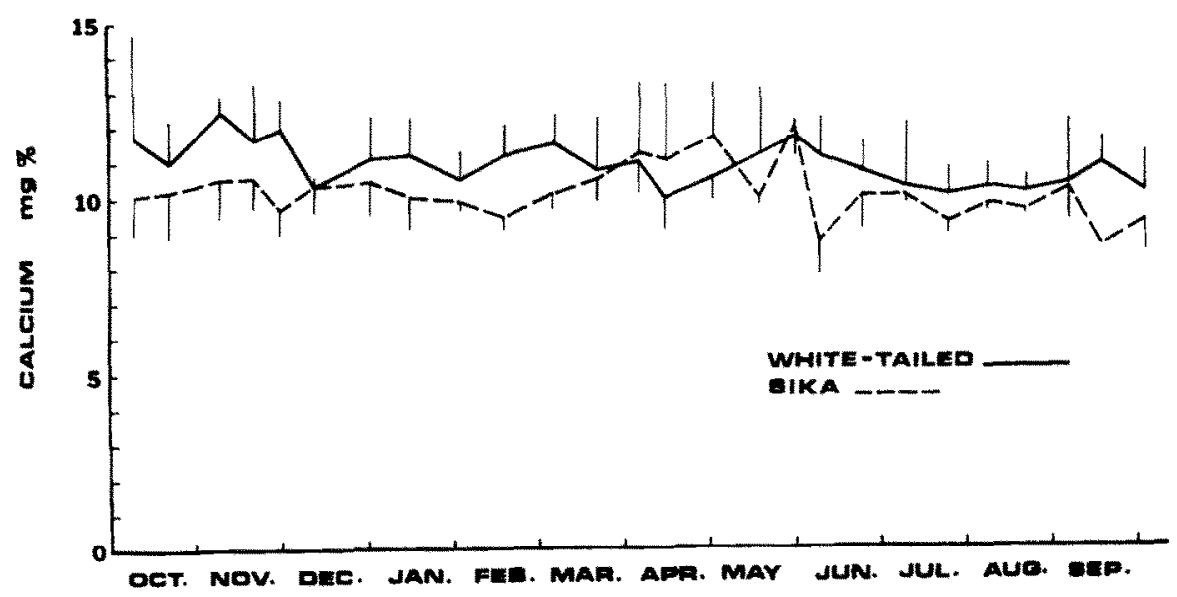

Fig. 5. Annual cycle of calcium in male white-tailed and sika fawns.

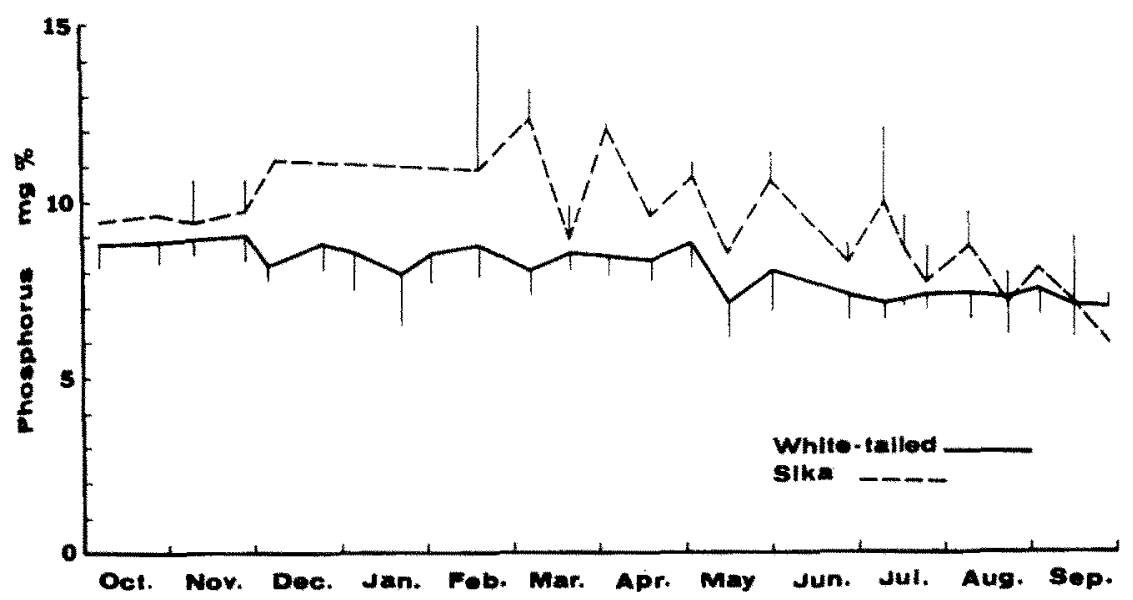

Fig. 6. Annual cycle of phosphorus in male white-tailed and sika fawns.

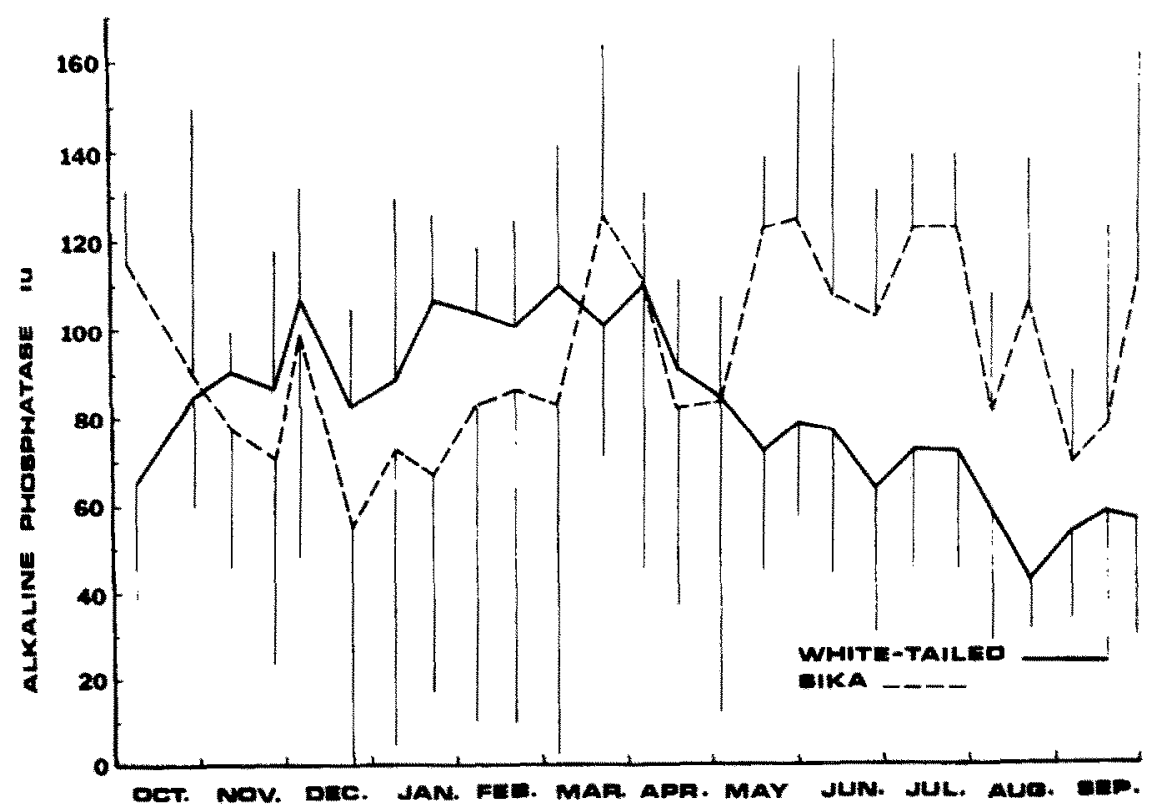

Fig. 7. Annual cycle of alkaline phosphatase activity in male white-tailed and sika fawns. 
Table 1. Mean annual values of blood parameters in five male white-tailed and three male sika deer fawns

\begin{tabular}{|c|c|c|c|c|}
\hline & \multicolumn{2}{|c|}{$\begin{array}{l}\text { White- } \\
\text { tailed }\end{array}$} & \multicolumn{2}{|c|}{ Sika } \\
\hline & $\overline{\mathrm{x}}$ & $\mathrm{SE}$ & $\overline{\mathrm{X}}$ & SE \\
\hline Testosterone $(\mathrm{ng} / \mathrm{ml})$ & 2.56 & 2.44 & 3.69 & 2,76 \\
\hline Androstenedione (ng/m) & 3.16 & 2.58 & 18.26 & 17,58 \\
\hline Thyroxine $(\mu \mathrm{g} / \mathrm{d} l)$ & 8.22 & 4.18 & 4.41 & 1.59 \\
\hline Calcium $(\mathrm{mg} \%)$ & 10.88 & 0.65 & 10.08 & 0.80 \\
\hline Phosphorus (mg\%) & 8.03 & 0.68 & 9.42 & 1.69 \\
\hline Alkaline Phosphatase (IU/I) & 81.89 & 19.45 & 95.35 & 22.65 \\
\hline
\end{tabular}

dione levels were correlated with $\mathrm{Ca}$ and $\mathbf{P}$ $(r=-0.47$ and -0.70 , respectively). Thyroxine levels were significantly $(P<0.05)$ correlated with AP activity $(r=-0.49)$. Calcium levels were correlated with P levels $(r=0.49)$.

In the antler initiation stage of the white-tails (March-May), $\mathrm{T}_{4}$ levels were significantly $(P<0.01)$ correlated with $\mathbf{P}$ and AP ( $r=0.80$ and 0.74 , respectively). Androstenedione levels were correlated with AP $(r=0.86)$ while P levels were correlated with AP $(r=0.69)$. In the antler initiation stage of the sika fawns (October-January) none of the blood parameters were significantly $(P>0.05)$ correlated indicating an independent relationship among all of these parameters studied.

In the white-tailed antler velvet stage (May-September) A levels were significantly correlated with $\mathrm{Ca}$ and $\mathrm{AP}$ ( $r=0.72$ and 0.67 , respectively) and AP was correlated with $\mathrm{Ca}$ and $\mathrm{P}(r=0.60$ and 0.68 , respectively). In the sika velvet stage (January-April) neither parameter was significantly $(P>0.05)$ correlated with other data, indicating an independent relationship in velvet stage among all of these parameters.

During the period of hardened spikes in the sika fawns, (April-September) $T_{4}$ levels were significantly $(P<0.05)$ correlated with AP $(r=-0.66)$ and $\mathrm{T}$ levels were significantly $(P<0.001)$ correlated with $\mathrm{A}$ $(r=-0.997)$, indicating an opposite trend of $\mathrm{T}$ and $\mathrm{A}$ in this stage.

\section{DISCUSSION}

In the annual hormone cycles of adult deer, high $\mathbf{T}$ levels are generally associated with rut, rubout, and mineralization of the velvet antlers (Brown, 1975). In our white-tailed fawns, higher $T$ titers occurred in November, before the buttons rubbed out. However, no rutting behavior was observed. In addition, the $T$ peak in March correlated with the further development of the pedicle, prior to the initiation of the first set of antlers (Fig. 1). This is similar to the $T$ peak found by Lincoln (1971) in red deer (Cerus elaphus) fawns. $T$ levels were not elevated, however, during the stage of antler growth in our yearlings. In the sika fawns, $T$ was also elevated just before vclvet spike growth. Rutting behavior was also not observed, and although $T$ levels declined after June, the deer maintained their hardened antlers afterward.

In the white-tails, A titers peaked similarly to $\mathrm{T}$, in November and March, and also followed the $T$ trend the remainder of the year (Fig. 2). It is not known if A had an additive effect to $T$ in these deer, but it is certainly possible. In the sikas, however, A peaked briefly in October, well before velvet spike growth. then declined and became elevated in the spring and summer. This prolonged period of elevated A titers during the period of hard antlers may explain why the antlers were not cast when the $T$ titers were low. It also suggests that $\mathrm{A}$ may be more important than $T$ in the antler growth cycle in lawns of this species.

$\mathrm{T}_{4}$ levels in the white-tailed fawns were mostly significantly $(P<0.05)$ higher month by month than those in sika fawns, suggesting a higher metabolic activity of the white-tails than of the sikas. Both whitetailed and sika fawns had higher $T_{4}$ levels in the winter and lower $T_{4}$ levels in the summer (Fig. 3) This is consistent with our findings in yearling whitew tailed deer (Chao \& Brown, unpublished data). Higher $\mathrm{T}_{4}$ titers during the winter are consistent with results found in roe deer fawns (Sempere \& Boissin, 1981) and support the concept of a synergistic role for $T_{4}$ in the initiation and growth of antlers in both species of fawns. Initial higher $T_{4}$ levels in all of the fawns might have been due to their young age. (Bube. nik \& Bubenik, 1978). The short-term decrease of $\mathrm{T}_{4}$ in both groups in early summer (June) might have been the consequence of higher ambient temperatures.

Relatively constant $\mathrm{Ca}$ and $\mathrm{P}$ levels in both fawn groups was expected, and represents the compensatory function of the parathyroid-calcitonin system (Hall, 1978). However, consistently higher $P$ levels in the sika fawns and relatively high $\mathrm{Ca}$ levels in the white-tail fawns might be species dependent. In the sika deer, however, both Ca and P values were higher than those reported by Dhindsa et al. (1975).

In the white-tailed fawns, AP activity was higher from January to April, during rub-out and while the buttons were hard. AP activity decreased when the first set of antlers was growing from late spring through the summer and early fall. This is in contrast to the study of Graham et al. (1962) which found that antler growth in the late spring and summer was marked by an increase in serum AP activity. In the sika fawns, the different antler growth cycle was reflected by differences in AP activity. The spikes were initiated in January and hardened in April, the latter following high $\mathbf{A P}$ activity. High AP activity (Fig. 6) was maintained as the sika fawns retained their hardened spikes. The postulated mineralization role of AP proposed by Fleisch \& Neuman, (1961) and Molello ef al. (1963), was thus demonstrated in this study.

\section{Correlations between blood parameters}

In the white-tailed fawns, a significant $(P<0.01)$ correlation between $T$ and $T_{4}$ levels suggests a relationship between the gonadal and thyroidal sys tems. This relationship, however, was not evident in the sika fawns. Similar $\mathrm{T}_{4}$ trends were found in all fawns. However, the different antler growth cycles in the two species were reflective of different $T$ cycles, indicating possibly different relationships between $T_{4}$ and $T$. Thyroxine might be involved in $\mathrm{Ca}$ and $\mathrm{P}$ homeostasis via AP activity in white-tailed deer, but this might not be true in sika fawns, as evidenced by little correlation between $\mathrm{T}_{4}$ and $\mathrm{Ca}$ or $\mathrm{P}$ and a negative correlation between $\mathrm{T}_{4}$ and AP activity.

During the antler initiation period of the whitetailed fawns, significant correlations between $T_{4}$ levels 
and $\mathrm{P}$ or $\mathrm{AP}$ indicated a close relationship between those parameters. High $\mathrm{T}_{4}$ levels during this stage might also suggest the synergistic role of $T_{4}$ in the initiation of antler growth. In the sika fawns, this relationship was very weak. However, higher $T_{4}$ levels in this stage does not exclude a synergistic role of $T_{4}$ on the initiation of antler growth.

During the antler velvet stage in the white-tailed fawns, the significant correlation between AP activity and both $\mathrm{Ca}$ and $\mathbf{P}$ indicated that $\mathrm{AP}$ might be involved in the $\mathrm{Ca}$ and $\mathrm{P}$ transport system as it is in other animals (Russell et al., 1972; Devgun et al., 1981). In the sika fawns, the lack of a significant correlation indicated a weak relationship between these parameters.

It is obvious from these studies that the endocrine control of the antler cycles of these two species differs. We can offer no logical explanation at present for the difference in the correlations between parameters between the two species. Results were no doubt affected by relatively small numbers of animals and fairly high standard errors. The lack of statistical correlations between parameters in the sika deer leads one to question the biological significance of the stronger correlations found in the white-tails. The fact that the white-tails go through a button stage as fawns, while the sikas grow spikes more similar to antlers, indicates that the latter species may have a more mature endocrine system at this early age. On the other hand. the sikas may in fact employ other hormones, as yet not measured, to control their antler cycles in a manner different from the white-tails. Due to these differences in juvenile antler development and endocrine levels one must be cautious in future comparisons of these species.

Acknowledgements-The authors wish to thank Dr. Ralph Bingham for his assistance in the statistical analysis of the data. This work was supported by the NIH grant No. SO6-RR-08107.

\section{REFERENCES}

Banks W. J., Epling G. P., Kainer R. A. \& Davis R. W. (1968) Antler growth and osteoporosis (a) I. Morphological and morphometric changes in the coastal compacta during the antler growth cycle. (b) I1. Gravimetric and chemical changes in the coastal compacta during the antler growth cycle. Anat. Rec. 162, 387-405.
BRown R. D. (1975) Some aspects of the endocrine control of antler growih in white-tailed deer (Odocolleus tirynanus). Ph.D. thesis. The Pennsylvania State University.

Bebraik G. A. \& BUbHNiK A. B. (1978) Thyroxine levels in male and female white-tailed deer (Odocoilets rirginianus). Can. J. Physiol. Pharm. 56, 945-949.

COWAN R. L.. HARTSOOK E. W. \& WhELAN J. B. (1969) Deer antler growth: an ideal test for the study of bone metabolism. Sci. Agric. 17, 3-4.

Devgly M. S., Paterson C. R. \& Martin B. T. (1981) Seasonal changes in the activity of serum alkaline phosphatase. Enzyme 26, 30!-305.

Dhindsa D. S.. Cochran T. H., Castro A., Swanson I. R. \& Mfrclafe J. (1975) Serum biochemical and electrophoretic values from four deer species and from prong horn antelope. Am. J. Vet. Res. 36, 1455.

FAUlKNer L. W., Zamora L., Jiminez M. \& Brown R. D. (1979) The effect of xylaxine hydrochloride on some blood parameters in white-tailed deer. NIH-MBS Symposium. Atlanta, Georgia, April 19. (Abstract E-3).

FleisCH H. \& NeumaN W. F. (1961) Mechanism of calcification: role of collagen, polyphosphates and phosphatase. Am. J. Physiol. 200, 1296-1300.

GILL J. L. (1978) Design and Analysis of Experiments in the Animal and Medical Science. Vol. 2, Iowa State Univ. Press, Ames.

Graham E. A., Rainey R. K., Albert E., Houghton E. H. \& Mover C.A. (1962) Biochemical investigations of deer antler growth. Part I. Alterations of deer blood chemistry resulting from osteogenesis. I. Bone and Joint Siry. $44 \mathrm{~A}, 482488$.

HALI. B. (1978) Components of skeletal growth 1. Hormones-the growth of antlers. pp. 213-215 In B. Hall (ed). Development and Cellular Skeletal Biology. Academic Press, New York.

Hillman. J. R., Davis R. W., Abdelbaki Y. Z. (1973) Cyclic bone remodeling in deer. Cell Tiss. Res. 12, 323 . 330.

LiNCOLN G. A. (1971) Puberty in a seasonally breeding male-the red deer stag (Cercus elaphus). J. Reprod. Fert. 25, 41-54.

Meister W. (1956) Changes in histological structure of the long bones of white-tailed deer during the growth of antlers. Anat. Rec. 124, 709-724.

Molfllo J. A., Eplivg G. P. \& Davis R. W. (1963) Histochemistry of the deer antler. Am. J. Vet. Re's, 24, 573-579.

Kussell. R. G. G., Monod A., Bonjouk J. P. \& FleisCh H. (1972) Relation between alkaline phosphatase and $\mathrm{Ca}^{-}$ATP in Ca transport. Nature, Lond. 240, 126.

Semperf A. J. \& Bolssin J. (1982) Ncuroendocrine and endocrine control of the antler cycle in roe deer. In Antler Detelopment in Cervidae (Edited by Brown R. D.l. Caesar Kleberg Wildlife Research Institute, Kingsville. In Press. 